\title{
An experimental and theoretical study on the regioselectivity of successive bromination sites of 7,8-dimethyl-2,4-diphenyl-3H-1,5- benzodiazepine. Efficient microwave assisted solventless synthesis of 4-phenyl-3H-1,5-benzodiazepines
}

\author{
Constantinos A. Tsoleridis, ${ }^{1 *}$ Minodora Pozarentzi, ${ }^{1}$ Sophia Mitkidou, ${ }^{2}$ and Julia \\ Stephanidou-Stephanatou ${ }^{1}$ \\ ${ }^{1}$ Laboratory of Organic Chemistry, Aristotle University of Thessaloniki, Thessaloniki, 54124, \\ Macedonia, Greece \\ ${ }^{2}$ Department of Science, School of Technological Applications, Technological Institute of \\ Kavala, Kavala, Greece \\ E-mail: tsolerid@chem.auth.gr
}

\begin{abstract}
A facile synthesis of 4-phenyl-1H-1,5-benzodiazepines from $o$-phenylenediamines and 1,3diketones in the presence of a catalytic amount of acetic acid has been achieved, in excellent yields, under microwave irradiation. This method is very simple and the reaction conditions are mild, environmentally friendly and more important, quick. Moreover, the complete assignment of ${ }^{1} \mathrm{H}$ - and ${ }^{13} \mathrm{C}$-NMR signals was achieved using $1 \mathrm{D}$ and $2 \mathrm{D}$ experiments in conjunction with DFT/GIAO calculated isotropic magnetic shieldings at the B3LYP density functional level. The geometries of selected compounds were optimized using the 6-31G(d) basis set, whereas the nuclear shielding constants were calculated using the $6-311 \mathrm{G}(\mathrm{d})$ basis set. The theoretical values were found very close to the experimental data. In addition, the allylic versus benzylic bromination as well as the regioselectivity of the successive bromination sites was studied on 7,8-dimethyl-2,4-diphenyl-1H-1,5-benzodiazepine, whereupon the enhanced reactivity of the 3$\mathrm{CH}_{2}$ group was established. Semiempirical (AM1, PM3) and DFT calculations confirmed that the free radical bromination selectivity of the above benzodiazepine is related to the stability of the intermediate radicals formed during the bromination process. In addition, the inversion energy of $\mathrm{H}_{2} \mathrm{C}(3)$ group was calculated by AM1 or PM3 using the reaction path method and was found to be $\sim 8.6$ or $\sim 9.0 \mathrm{kcal} / \mathrm{mol}$, respectively, very close to the experimental value of $c a .12 .4$ $\mathrm{kcal} / \mathrm{mol}$.
\end{abstract}

Keywords: Allylic/benzylic bromination, 1,5-benzodiazepines, DFT GIAO calculations, inversion energy, microwave synthesis, regioselectivity 


\section{Introduction}

Benzodiazepines have recently received a lot of attention because of their wide range of therapeutic and pharmacological properties. Many members of the diazepine family are nowadays widely used as anti-anxiety, antidepressant, sedative, hypnotic, anticonvulsant, analgesic and anti-inflammatory agents. ${ }^{1-3}$ Benzodiazepine derivatives also find commercial use as dyes for acrylic fibers. ${ }^{4}$ In addition, 1,5-benzodiazepines are important intermediates for the synthesis of various fused ring heterocyclic compounds such as oxazino-, oxadiazolo-, furanoand triazolo-benzodiazepines. ${ }^{5}$ Due to their wide range of biological, industrial and synthetic applications, the development of mild, efficient and environmentally friendly protocols continues to be a challenging endeavour in synthetic organic chemistry. As a result, various methods concerning the synthesis of 2,3-dihydro- $1 H$-1,5-benzodiazepines appeared recently in the literature $^{6-7}$ To the contrary, the synthesis of $3 H-1,5$-benzodiazepines has received little attention and only a few methods are reported in the literature for their preparation. ${ }^{8-9}$ Moreover, bromo substituted derivatives continue to be very important synthetic intermediates for pharmaceutical and other chemical related industries and the issue of allylic over benzylic or aromatic ring bromination is still very challenging. So, in this article as a part of a more extensive study on the chemistry of benzodiazepines we wish to report an efficient and rapid synthesis of $3 H-1,5$-benzodiazepines under "green chemistry" conditions (microwave irradiation without solvent) and a study of their allylic versus benzylic bromination as well as the regioselectivity of their successive bromination sites.

\section{Results and Discussion}

This synthesis was carried out simply by mixing $o$-phenylenediamines $\mathbf{1}$ with 1,3-diketones 2 (in a 1.5:1 molar ratio) in the presence of a catalytic amount of acetic acid and irradiating in a Milestone Ethos 1600 microwave oven (Scheme 1), whereupon the benzodiazepine derivatives 3 were obtained in almost quantitative yield (Table 1). However, from the reaction of the 3-methyl substituted diketone $\mathbf{2 b}$ with diamine $\mathbf{1 b}$ the benzimidazole $\mathbf{4}$ was also isolated in $20 \%$ yield. The reaction between diamine 1a and diketone $2 \mathbf{c}$ was also repeated at room temperature for $24 \mathrm{~h}$, whereupon benzodiazepine $\mathbf{3 b}$ was isolated in only $46 \%$ yield. It should be mentioned that the 2,4-diphenyl-3H-1,5-benzodiazepine $\mathbf{3 b}$ has been prepared by standard methods in comparatively low yield $(\sim 40-45 \%),{ }^{9 a}$ whereas the synthesis of the 7,8-dimethyl derivative $\mathbf{3 d}$ has been reported previously from 4,5-dimethyl-1,2-phenylenediamine and diphenylpropynone in low yield $(21 \%) .^{10}$

In order to study the bromination selectivity (benzylic and/or allylic), the brominations were performed on the 7,8-dimethyl derivative 3d with NBS under reflux in carbon tetrachloride solution using a $200 \mathrm{~W}$ light bulb resulting in the brominated derivatives 5-10 (Scheme 2). In contrast, the use of NBS in the presence of benzoylperoxide or 2,2'- azobisisobutyronitrile 
(AIBN) was unsuccessful, due to the formation of many products.<smiles>[R]c1cc(N)c(N)cc1[R]</smiles>
a $\mathrm{R}^{1}=\mathrm{R}^{2}=\mathrm{H}$
a $\mathrm{R}^{3}=\mathrm{CH}_{3}, \mathrm{R}^{4}=\mathrm{H}$
b $\mathrm{R}^{1}=\mathrm{R}^{2}=\mathrm{CH}_{3}$
b $\mathrm{R}^{3}=\mathrm{R}^{4}=\mathrm{CH}_{3}$
c $\mathrm{R}^{3}=\mathrm{Ph}, \mathrm{R}^{4}=\mathrm{H}$
a $\mathrm{R}^{1}=\mathrm{R}^{2}=\mathrm{R}^{4}=\mathrm{H}, \quad \mathrm{R}^{3}=\mathrm{CH}_{3}$
b $\mathrm{R}^{1}=\mathrm{R}^{2}=\mathrm{R}^{4}=\mathrm{H}, \quad \mathrm{R}^{3}=\mathrm{Ph}$
c $\mathrm{R}^{1}=\mathrm{R}^{2}=\mathrm{R}^{3}=\mathrm{CH}_{3}, \quad \mathrm{R}^{4}=\mathrm{H}$
d $\mathrm{R}^{1}=\mathrm{R}^{2}=\mathrm{CH}_{3}, \quad \mathrm{R}^{3}=\mathrm{Ph}, \mathrm{R}^{4}=\mathrm{H}$
e $\mathrm{R}^{1}=\mathrm{R}^{2}=\mathrm{R}^{4}=\mathrm{CH}_{3}, \mathrm{R}^{3}=\mathrm{Ph}$

(a) MW, acetic acid (cat. amount)

$1: 2=1.5: 1$

(b) In the case of reaction of $\mathbf{1 b}$ with $\mathbf{2 b}$ compound 4 was also obtained

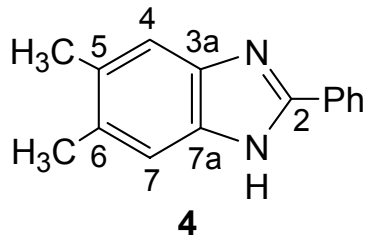

Scheme 1. Synthesis of 3H-1,5-benzodiazepines 3.

Table 1. Preparation of 4-phenyl-3H-1,5-benzodiazepines 3 using microwaves

\begin{tabular}{ccccc}
\hline Reactants & Product & \multicolumn{3}{c}{ Milestone microwave oven } \\
\cline { 3 - 5 } & 3 & $\begin{array}{c}\text { Power } \\
(\mathrm{W})\end{array}$ & $\begin{array}{c}\text { Time } \\
(\mathrm{min})\end{array}$ & Yield \% \\
\hline $\mathbf{1 a}+\mathbf{2 a}$ & $\mathbf{3 a}$ & 150 & 3 & 93 \\
$\mathbf{1 a}+\mathbf{2 c}$ & $\mathbf{3 b}$ & 250 & 10 & 95 \\
$\mathbf{1 b}+\mathbf{2 a}$ & $\mathbf{3 c}$ & 150 & 3 & 96 \\
$\mathbf{1 b}+\mathbf{2 c}$ & $\mathbf{3 d}$ & 250 & 8 & 97 \\
$\mathbf{1 b}+\mathbf{2 b}$ & $\mathbf{3 e}$ & 200 & 2 & $62^{\mathrm{a}}$ \\
\hline
\end{tabular}

${ }^{\text {a }}$ Benzimidazole 4 was also isolated in $20 \%$ yield.

Reaction of 3d with 1.1 equiv. of NBS revealed that allylic bromination was the favored initial reaction site. After the first $5 \mathrm{~min}$. TLC of the reaction mixture showed the presence of compound 5 and unreacted 3d. After 30 min compound 3d was consumed and two spots appeared on the TLC plate, corresponding to a mixture of the 3-bromo derivative 5 (20\%) and the 3-bromo-7-bromomethyl derivative 6 (45\%). Reaction with 2.2 equiv. of NBS resulted in 6 $(52 \%)$ and the tribromo derivative 7 (24\%). Subsequent reaction with 3.3 equiv. of NBS gave compound 7 (46\%) and the tetrabromo derivative 8 (26\%) and reaction with 4.4 equiv. of NBS 
gave compound $8(50 \%)$ and the pentabromo derivative $9(23 \%)$. However, with 6 equiv. of NBS the pentabromo derivative 9 was regiospecifically formed in excellent yield (95\%). It should also be noted that the brominated compounds $\mathbf{6 - 9}$ were formed with a satisfactory degree of regioselectivity $(\sim 2: 1)$, in almost all cases favoring the less brominated derivatives. Finally, by using even larger amounts of NBS ( 7 equivalents or more) and longer reaction times $(\geq 4 \mathrm{~h})$ a small amount of the hexabromo derivative 10 was additionally obtained in $14 \%$ yield.

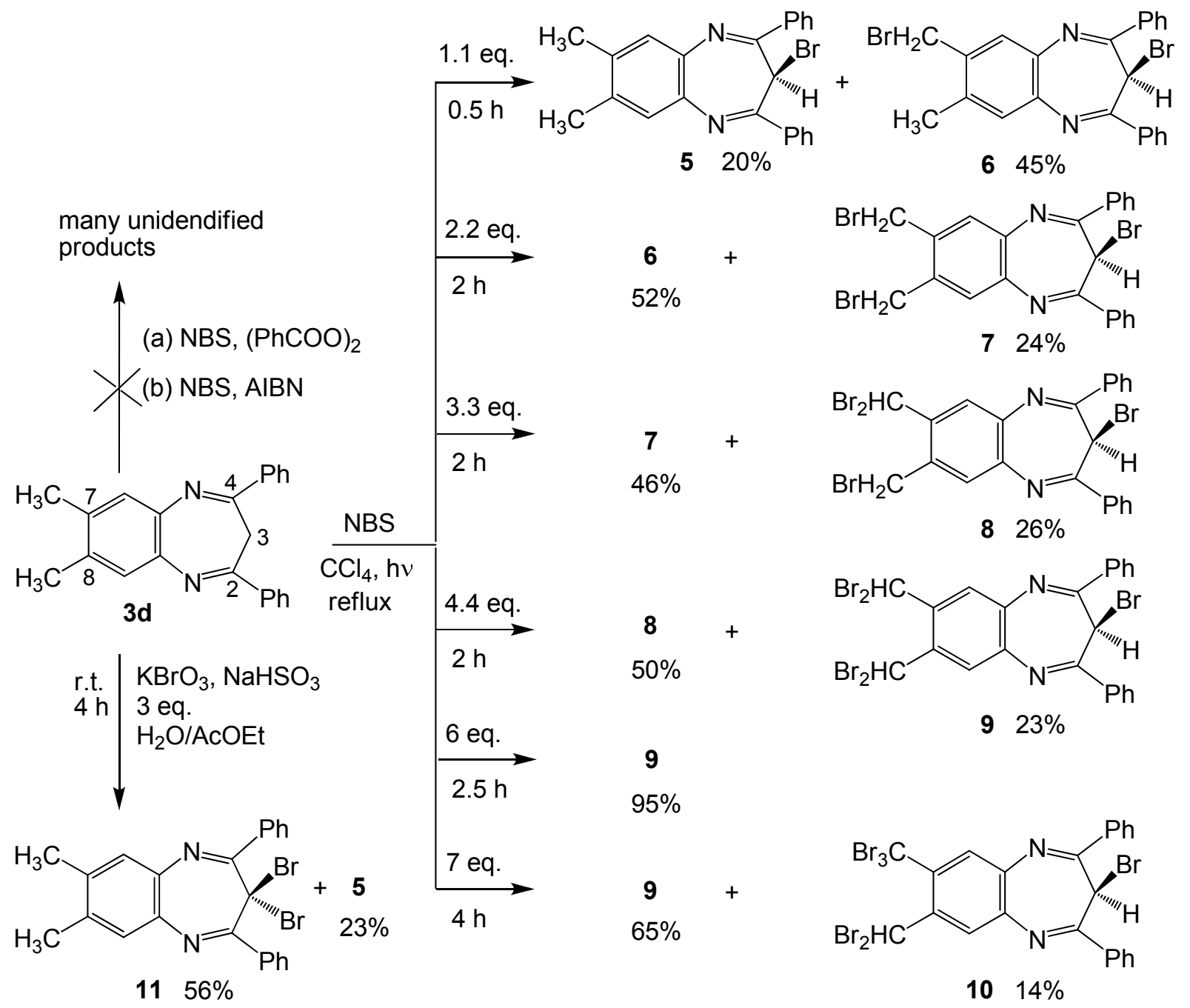

Scheme 2. Bromination products of 7,8-dimethyl-2,4-diphenyl-3H-1,5-benzodiazepine (3d).

From this study it can be concluded that the $\mathrm{H}_{2} \mathrm{C}(3)$ allylic group appears to be more reactive than the 7- or 8-methyl groups towards bromination under radical conditions. However, dibromination on the $\mathrm{BrHC}(3)$ group was not observed, but subsequent bromination occurs preferentially on the benzylic positions. Monobromination of the $\mathrm{H}_{2} \mathrm{C}(3)$ group of the benzodiazepine 3b occurs also with NBS without the use of light or benzoylperoxide. ${ }^{9 b}$ Nevertheless, dibromination in the 3 position of benzodiazepine $\mathbf{3 d}$ was possible by using the 
$\mathrm{KBrO}_{3} / \mathrm{NaHSO}_{3}$ reagent. In a typical experiment, ${ }^{11}$ to a two-phase system comprised of ethyl acetate involving 3d and aqueous $\mathrm{KBrO}_{3}$ (3 equiv.), an aqueous solution of $\mathrm{NaHSO}_{3}$ (3 equiv.) was added and the mixture was allowed to react at room temperature for $4 \mathrm{~h}$, whereupon the 3,3dibromo derivative $\mathbf{1 1}$ was isolated as the main reaction product in 56\% yield along with the 3 bromobenzodiazepine $\mathbf{5}$ in $23 \%$ yield (Scheme 2).
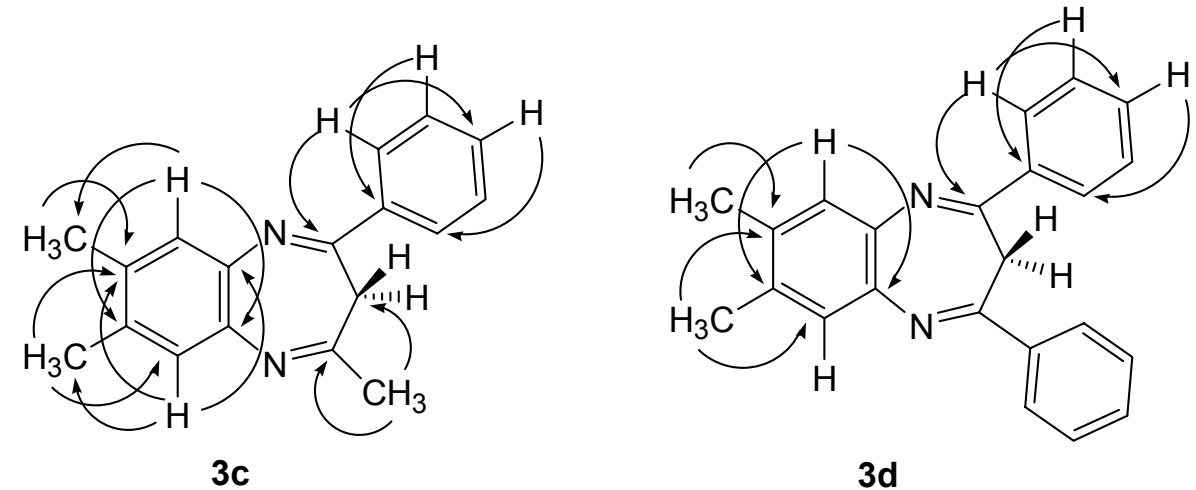

3d
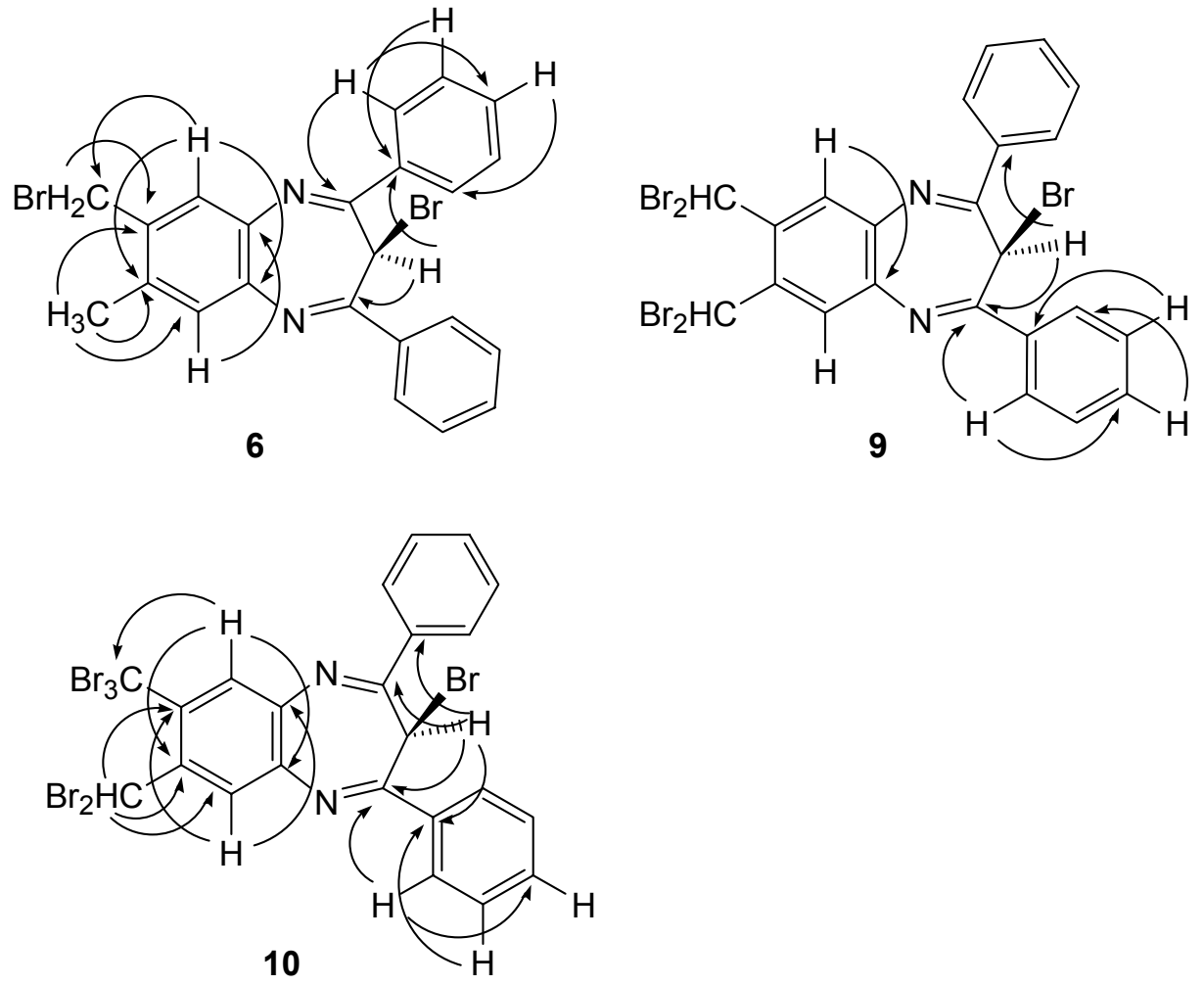

Figure 1. COLOC correlations observed for compounds $\mathbf{3 c}, \mathbf{3 d}, \mathbf{6}, \mathbf{9}$ and $\mathbf{1 0}$.

\section{Structure assignment by NMR spectra investigations}

The structural assignments of the compounds studied were established by analysis of their NMR spectra $\left({ }^{1} \mathrm{H},{ }^{13} \mathrm{C}\right.$, DEPT, COSY H-H, NOESY H-H, HETCOR C-H, and COLOC C-H). In 
Figure 1 the long range $\mathrm{C}-\mathrm{H}$ correlations (COLOC) used for the structural assignments of compounds 3c, 3d, 6, 9 and 10 are depicted.

Concerning the NMR study of benzodiazepines $\mathbf{3}$, due to the slow inversion of the diazepine cycloheptatriene ring at ambient temperature, the 3-methylene protons give a very broad, hardly distinguished, ${ }^{1} \mathrm{H}-\mathrm{NMR}$ signal at $\delta \sim 3.5-4.0$. At very low temperatures, where the inversion practically does not occur, the signal of each proton is differentiated. ${ }^{12}$ The signal at $\delta \sim 2.5$ can be assigned to the proton in the endo site of the diazepine ring, where it is shielded by both $\mathrm{C}=\mathrm{N}$ anisotropy cones $(+)$.
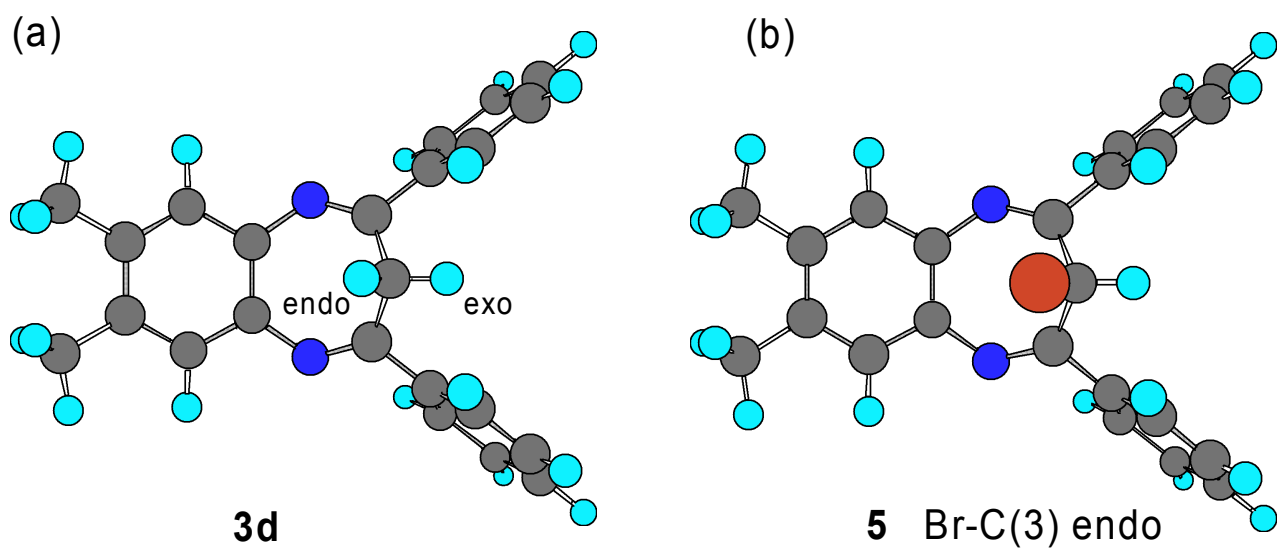

Figure 2. Molecular models (AM1) of: (a) Compound 3d with endo-exo configuration of cycloheptatriene methylene protons; (b) 3-Bromo derivative 5 with endo configuration of $\mathrm{Br}$.
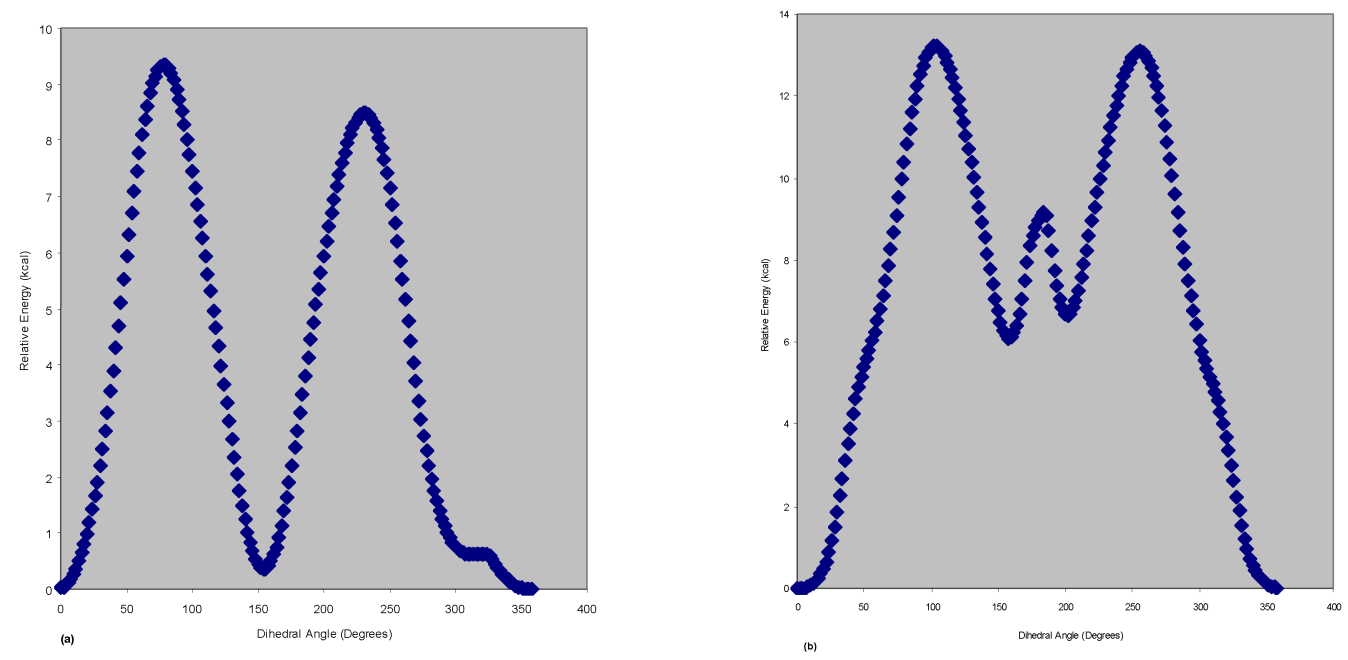

Figure 3. Variation of the relative energy of formation $\left(\Delta \Delta \mathrm{H}_{\mathrm{f}}\right)$ versus the dihedral angle between $\mathrm{Br}-\mathrm{CH}-\mathrm{C}(8)-\mathrm{C}(7)$ as the group $\mathrm{Br}_{2} \mathbf{H C}-\mathrm{C}(8)$ is rotating: (a) In compound $\mathbf{9}$ and (b) in compound 10 (AM1). 
On the other hand, the exo proton being closer to the deshielding cones of the two phenyls and of the two $\mathrm{C}=\mathrm{N}$ bonds resonates at much lower field $(\delta \sim 5.0)$ (Fig. 2a). In the case of compound 3e, the 3-methyl group prefers, in order to diminish the repulsive interactions, the endo conformation, so the methyl protons show a doublet at $\delta=0.85(J=7.15 \mathrm{~Hz})$, whereas the 3-methine proton gives a quartet at $\delta=5.56(J=7.15 \mathrm{~Hz})$. The $\operatorname{BrHC}(3)$ methine protons of all compounds 5-10 being under the influence of the two phenyls, the two $\mathrm{N}=\mathrm{C}$ bonds, and additionally of the bromine atom (Fig. 2b) resonate at $\delta \sim 7.0$. In compound 9 the $\mathrm{Br}_{2} \mathrm{CH}-$ groups are rotating relative to each other slowly at the NMR time scale, like two gear wheels, resulting to the very broad $\mathrm{C}(6 / 9)$ and $\mathrm{C}(7 / 8)$ carbon signals. Similar broadening is observed for the $\mathrm{HC}(6 / 9)$ and the $\mathrm{Br}_{2} \mathrm{HC}-\mathrm{C}(7 / 8)$ proton signals. As a result of the above broadening, COLOC correlations could not be observed for the carbons $\mathrm{C}(6 / 9)$ and $\mathrm{C}(7 / 8)$ of compound 9 . For the same reason, COLOC correlations could not be observed for the $\mathrm{H}_{2} \mathrm{C}(3)$ protons of compounds 3a-3d (Fig. 1).

An AM1 simulation of the rotation of $\mathrm{Br}_{2} \mathrm{HC}-\mathrm{C}(8)$ group at $298 \mathrm{~K}$ gave a sinusoid like curve for the variation of the relative energy of formation $\left(\Delta \Delta H_{f}\right)$ versus the dihedral angle between the atoms in group $\mathrm{Br}-\mathrm{C}-\mathrm{C}(8)-\mathrm{C}(7)$ with two energy barriers of $\sim 9.3 \mathrm{kcal}$ for a full rotation (Fig. 3a). In compound 10 the $-\mathrm{CBr}_{3}$ group is more sterically hindering than the $\mathrm{CHBr}_{2}$ group in 9 and the AM1 approximation of the rotation of the two substituted methyls at $C(7 / 8)$ gave a more complicated sinusoid like line with two energy barriers of $\sim 13.2 \mathrm{kcal}$ for a full rotation (Fig. $3 \mathrm{~b}$ ). As a result, the rotation of both groups is prohibited and the NMR signals for carbon and proton atoms in compound $\mathbf{1 0}$ are of normal width.

For comparison reasons in Table S1 (see Supporting Information) the chemical shifts for ${ }^{13} \mathrm{C}$ NMR spectra of all synthesized compounds are summarized. From this table it can be concluded that only small differences have been observed for similar atoms, especially in the case of bromides 5-10, formed by the stepwise bromination. In order to clear up the ambiguity for the assignment of the chemical shifts, in the cases with non-identical substituents at $\mathrm{C}(2 / 4)$ or at $\mathrm{CH}_{3}-\mathrm{C}(7 / 8)$, the isotropic magnetic shieldings for the atoms in question have been calculated ${ }^{13,14}$ by the DFT/GIAO method and their relative values to TMS, $\triangle \mathrm{IMS}$, are presented in Table 2. From the comparison of experimental and calculated chemical shifts a good coincidence for the trend of the change of chemical shifts for different substituents in positions $2 / 4$ and $7 / 8$ is found. Once the chemical shifts of $\mathrm{C}(2) / \mathrm{C}(4), \mathrm{C}(5 \mathrm{a}) / \mathrm{C}(9 \mathrm{a})$ and $\mathrm{C}\left(1^{\prime}\right) / \mathrm{C}\left(1^{\prime \prime}\right)$ pairs have been established, it was possible to distinguish and assign the rest of chemical shifts using COLOC correlations (Fig. 1). In the cases where the ${ }^{13} \mathrm{C}$ chemical shift differences are very small or the ${ }^{1} \mathrm{H}$ chemical shifts are overlapping the ambiguity in assignment, although meaningless, still remains.

\section{Theoretical study on bromination}

The molecular model of benzodiazepine 3d was investigated by semiempirical MO calculations (AM1 and PM3 models) (Fig. 2a). The inversion energy of the $\mathrm{H}_{2} \mathrm{C}(3)$ group determined experimentally by variable temperature ${ }^{1} \mathrm{H}-\mathrm{NMR}$ measurements on related compounds gave $\Delta G^{*}$ values of $c a .12 .4 \mathrm{kcal} / \mathrm{mol}^{12}$ The same inversion energy calculated by AM1 or PM3 using the 
reaction path method was found to be $\sim 8.6$ or $\sim 9.0 \mathrm{kcal} / \mathrm{mol}$, respectively, very close to the experimental value.

The molecular model of the 3-bromo derivative 5 is depicted in Figure $2 b$ as the 5-endo conformer. In the case of 5-exo derivative the Van der Waals interactions would be stronger, therefore the bromine takes preferentially the endo configuration with the energy difference being $\Delta \Delta H_{f}=6.47 / 4.29 \mathrm{kcal} / \mathrm{mol}(\mathrm{AM} 1 / \mathrm{PM} 3)$. The inversion energy of $\mathrm{BrHC}(3)$ group is calculated to be $\sim 14.1 / \sim 10.6 \mathrm{kcal} / \mathrm{mol}(\mathrm{AM} 1 / \mathrm{PM} 3)$.

$N$-Bromosuccinimide (NBS) has been used quite extensively, especially for allylic and benzylic brominations. The authors anticipate that under the reaction conditions (reflux in $\mathrm{CCl}_{4}$, light and/or radical initiators) bromine and bromine radicals are produced in low concentration and that the rate determining step for benzylic bromination is the hydrogen abstraction. ${ }^{15}$ The ease of hydrogen abstraction and the stability of the resulting radical can override other factors, such as steric effects leading to the selectivity of radical formation and subsequently to the bromination product. Hence, in the present study the stability of the successive radicals was studied.

Table 2. Isotropic magnetic shieldings relative to $\mathrm{TMS}^{a}(\Delta \mathrm{IMS})$ in conjunction with the chemical shifts for some carbon and proton nuclei of selected compounds.

\section{a) Benzodiazepines 3a-3d}

\begin{tabular}{lrrrrrrrr}
\hline & \multicolumn{2}{c}{ 3a } & \multicolumn{2}{c}{ 3b } & \multicolumn{2}{c}{ 3c } & \multicolumn{3}{c}{ 3d } \\
\hline Atom & \multicolumn{1}{c}{$\Delta \mathrm{IMS}^{b}$} & \multicolumn{1}{c}{ ppm } & \multicolumn{1}{c}{$\Delta \mathrm{IMS}$} & \multicolumn{1}{c}{ ppm } & \multicolumn{1}{c}{$\Delta \mathrm{IMS}$} & \multicolumn{1}{c}{ ppm } & \multicolumn{1}{c}{$\Delta \mathrm{IMS}$} & \multicolumn{1}{c}{ ppm } \\
\hline 2 & 158.57 & 157.9 & 155.53 & 154.1 & 157.22 & 156.4 & 152.52 & 153.0 \\
4 & 152.50 & 153.3 & 155.53 & 154.1 & 150.85 & 151.9 & 152.52 & 153.0 \\
$5 \mathrm{a}$ & 146.35 & 140.2 & 147.15 & 140.7 & 144.78 & 138.5 & 145.62 & 138.8 \\
6 & 134.60 & 127.6 & 135.22 & 128.7 & 135.05 & 128.7 & 135.78 & 129.1 \\
7 & 129.01 & 125.2 & 129.54 & 125.4 & 140.35 & 133.8 & 141.24 & 134.6 \\
8 & 129.21 & 125.0 & 129.54 & 125.4 & 140.67 & 134.1 & 141.24 & 134.6 \\
9 & 134.22 & 128.4 & 135.22 & 128.7 & 134.84 & 128.0 & 135.78 & 129.1 \\
9a & 147.21 & 140.6 & 147.15 & 140.7 & 145.54 & 138.2 & 145.62 & 138.8 \\
$1^{\prime}$ & 142.42 & 137.0 & 144.02 & 137.2 & 142.43 & 137.1 & 142.33 & 137.5 \\
$1^{\prime \prime}$ & 28.68 & 27.00 & 144.02 & 137.2 & 28.63 & 26.8 & 142.33 & 137.5 \\
H-C(6) & 7.62 & 7.54 & 7.68 & 7.61 & 7.43 & 7.31 & 7.52 & 7.38 \\
H-C(9) & 7.54 & 7.45 & 7.68 & 7.61 & 7.32 & 7.22 & 7.52 & 7.38 \\
\hline
\end{tabular}


b) Brominated Benzodiazepines 5-8

\begin{tabular}{lcccccccc}
\hline & \multicolumn{3}{c}{$\mathbf{5}$} & \multicolumn{3}{c}{$\mathbf{6}$} & \multicolumn{3}{c}{$\mathbf{7}$} & \multicolumn{1}{c}{$\mathbf{8}$} \\
\hline Atom & \multicolumn{1}{c}{$\Delta \mathrm{IMS}$} & \multicolumn{1}{c}{ ppm } & \multicolumn{1}{c}{$\Delta \mathrm{IMS}$} & \multicolumn{1}{c}{ ppm } & \multicolumn{1}{c}{$\Delta \mathrm{IMS}$} & \multicolumn{1}{c}{ ppm } & \multicolumn{1}{c}{$\Delta \mathrm{IMS}$} & \multicolumn{1}{c}{ ppm } \\
\hline 2 & 137.32 & 149.4 & 156.89 & 151.2 & 157.30 & 151.9 & 158.30 & 152.9 \\
4 & 137.32 & 149.4 & 156.36 & 150.6 & 157.58 & 151.9 & 157.71 & 152.5 \\
$5 \mathrm{a}$ & 127.57 & 139.1 & 145.62 & 139.1 & 147.68 & 141.1 & 146.62 & 141.50 \\
6 & 120.76 & 129.5 & 139.10 & 130.5 & 139.54 & 131.5 & 137.69 & 131.3 \\
7 & 124.39 & 136.6 & 142.77 & 135.1 & 144.25 & 135.1 & 144.15 & 131.1 \\
8 & 124.39 & 136.6 & 145.23 & 136.4 & 144.08 & 135.1 & 136.66 & 130.7 \\
9 & 120.76 & 129.5 & 138.06 & 130.7 & 139.13 & 131.5 & 136.07 & 130.7 \\
$9 \mathrm{a}$ & 127.57 & 139.1 & 146.23 & 141.2 & 147.47 & 141.1 & 148.16 & 141.55 \\
$1^{\prime}$ & 127.18 & 137.4 & 146.12 & 137.2 & 145.51 & 136.7 & 145.21 & 136.5 \\
$1^{\prime \prime}$ & 127.18 & 137.4 & 145.29 & 127.9 & 145.18 & 136.7 & 144.97 & 136.6 \\
H-C(6) & 7.39 & 7.49 & 7.72 & 7.67 & 7.70 & 7.70 & 8.44 & 8.26 \\
H-C(9) & 7.39 & 7.49 & 7.58 & 7.52 & 7.65 & 7.70 & 8.00 & 7.62 \\
\hline
\end{tabular}

${ }^{a}$ Isotropic magnetic shielding for TMS calculated by B3LYP/6-31G(d)//B3LYP/6-311G(d) method: For ${ }^{1} \mathrm{H} \mathrm{IMS}_{\mathrm{TMS}}=32.20$; for ${ }^{13} \mathrm{CIMS}_{\mathrm{TMS}}=183.60 \mathrm{ppm} .{ }^{b}$ Relative $\Delta \mathrm{IMS}=\mathrm{IMS}_{\mathrm{TMS}}-$ $\mathrm{IMS}_{\mathrm{X}}$ for magnetic nuclei X.

Since $\mathrm{CCl}_{4}$ is a neutral non-polar solvent, the calculation of geometries and thermodynamic quantities of the species in vacuum resembles that of the low concentration solution conditions, where solvent effects are negligible.

Among the methods, semiempirical calculations give rapid results, although they are considered not to be quantitatively accurate. As long as relative energies are compared the possible errors of calculations may be ignored. 


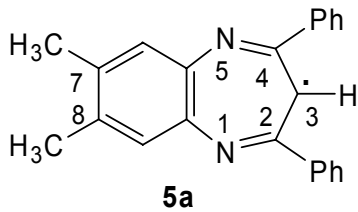<smiles>[CH2]c1cc2c(cc1C)N=C(c1ccccc1)[C@H](Br)C(c1ccccc1)=N2</smiles>

$6 a$<smiles>BrCc1cc2c(cc1C(Br)Br)N=C(c1ccccc1)[C@H](Br)C(c1ccccc1)=N2</smiles>

$8 a$<smiles>Cc1cc2c(cc1C(Br)(Br)Br)N=C(c1ccccc1)[C@H](Br)C(c1ccccc1)=N2</smiles><smiles>[CH]c1cc2c(cc1C)N=C(c1ccccc1)CC(c1ccccc1)=N2</smiles>

$5 b$<smiles>Cc1cc2c(cc1C)N=C(c1ccccc1)C(Br)C(c1ccccc1)=N2</smiles><smiles>Cc1cc2c(cc1C)N=C(c1ccccc1)C(Br)C(c1ccccc1)=N2</smiles>

$8 b$<smiles>Cc1cc2c(cc1C)C(c1ccccc1)=NC(c1ccccc1)=C(Br)C(c1ccccc1)=N2</smiles><smiles>Cc1cc2c(cc1CBr)N=C(c1ccccc1)[C@H](Br)C(c1ccccc1)=N2</smiles>

$7 b$<smiles>CC(Br)c1cc2c(cc1C(Br)Br)N=C(c1ccccc1)[C@H](Br)C(c1ccccc1)=N2</smiles>

$9 a$

$9 \mathrm{~b}$

Scheme 3. Possible intermediate radicals formed during the bromination of benzodiazepine 3d.

Table 3. Calculated heats of formation $\Delta H_{f}$ (AM1 and PM3) and total energies (UB3LYP/ 6$31 \mathrm{G}(\mathrm{d}))$ of possible radical intermediates as well with their relative stabilities $\left(\Delta \Delta H_{f}\right)$.

\begin{tabular}{|c|c|c|c|c|c|c|c|c|c|}
\hline AM1 & \multicolumn{4}{|c|}{ UHF } & \multicolumn{2}{|c|}{ PM3 } & \multicolumn{2}{|c|}{ UHF } & \\
\hline \multicolumn{4}{|c|}{ Calcd $\Delta H_{f}(\mathrm{kcal} / \mathrm{mol})$} & $\Delta \Delta H_{f}$ & \multicolumn{4}{|c|}{ Calcd $\Delta H_{f}(\mathrm{kcal} / \mathrm{mol})$} & $\Delta \Delta H_{f}^{\mathrm{a}}$ \\
\hline $5 \mathbf{a}$ & 131.56 & $5 \mathbf{b}$ & 132.09 & 0.53 & $5 \mathbf{a}$ & 114.01 & $\mathbf{5 b}$ & 119.06 & 5.05 \\
\hline $6 \mathbf{a}$ & 140.54 & $11 b$ & 140.76 & $\left.0.22^{b}\right)$ & $6 \mathbf{a}$ & 126.56 & $11 b$ & 124.84 & $-1.72^{b}$ \\
\hline $7 \mathbf{a}$ & 146.31 & $7 \mathbf{b}$ & 142.51 & -3.80 & $7 \mathbf{a}$ & 133.41 & $7 \mathbf{b}$ & 135.10 & 1.69 \\
\hline $8 \mathbf{a}$ & 148.76 & $8 \mathbf{b}$ & 152.13 & 3.37 & $8 \mathbf{a}$ & 144.66 & $\mathbf{8 b}$ & 140.76 & -3.90 \\
\hline $9 \mathbf{a}$ & 159.01 & $9 \mathrm{~b}$ & 156.85 & -2.16 & 9a & 151.56 & $9 \mathrm{~b}$ & 153.41 & 1.85 \\
\hline DFT & \multicolumn{3}{|c|}{$E_{\text {total }}{ }^{\mathrm{c}}$} & & \multicolumn{2}{|c|}{$E_{\text {total }}{ }^{\mathrm{c}}$} & \multicolumn{3}{|l|}{$\Delta E^{\mathrm{d}}$} \\
\hline $5 \mathbf{a}$ & \multicolumn{3}{|c|}{-997.370040} & $5 \mathbf{b}$ & \multicolumn{2}{|c|}{-997.357762} & \multicolumn{3}{|c|}{7.71} \\
\hline $6 a$ & \multicolumn{3}{|c|}{-3568.457390} & $11 \mathrm{~b}$ & \multicolumn{2}{|c|}{-3568.461932} & \multicolumn{3}{|c|}{$-2.85^{b}$} \\
\hline $7 \mathbf{a}$ & \multicolumn{3}{|c|}{-6139.560250} & $7 \mathbf{b}$ & \multicolumn{2}{|c|}{-6139.563327} & \multicolumn{3}{|c|}{-1.93} \\
\hline $8 \mathbf{a}$ & \multicolumn{3}{|c|}{-8710.666361} & $8 b$ & \multicolumn{2}{|c|}{-8710.664697} & \multicolumn{3}{|c|}{1.04} \\
\hline $9 \mathbf{a}$ & \multicolumn{3}{|c|}{-11281.760882} & $9 b$ & \multicolumn{2}{|c|}{-11281.754440} & \multicolumn{3}{|c|}{4.04} \\
\hline
\end{tabular}

${ }^{\mathrm{a}} \Delta \Delta H_{f}$ is the difference between the heat of formation of isomers $\mathbf{b}$ and $\mathbf{a}(\mathrm{kcal} / \mathrm{mol}){ }^{\mathrm{b}}$ For $\mathbf{1 1} \mathbf{b}-$ 6a. ${ }^{\mathrm{c}}$ In Hartrees, 1 Hartree $=627.51 \mathrm{kcal} / \mathrm{mol} .{ }^{\mathrm{d}}$ Difference in $E_{\text {total }}$ between the isomers $\mathbf{b}$ and $\mathbf{a}$ $(\mathrm{kcal} / \mathrm{mol})$ 
On the other hand, high level ab initio calculations are much more computational demanding but could give accurate quantitative results. In the present study, we have used the AM1 and PM3 models in order to compare them, but also to compare with the experimental results. Moreover, DFT calculations (UB3LYP/6-31G(d)) constitute an excellent compromise between computational cost and accurate energetic results. Therefore, DFT calculations have been carried out in order to use these results as reference. In Scheme 3 some possible intermediate radicals formed during the bromination process of benzodiazepine $\mathbf{3 d}$ are depicted. The radicals labeled with a lead to the products obtained experimentally, whereas those labeled with $\mathbf{b}$ are considered imaginary. All calculated results are shown in Table 3.

Between the radicals $\mathbf{5 a}$ and $\mathbf{5 b}$, which could be formed initially, $\mathbf{5 a}$ is calculated to be more stable by all methods, probably due to the extra stabilization gained by the two $\mathrm{C}(\mathrm{Ph})=\mathrm{N}$ groups. In addition, the 3-endo hydrogen is in a favored position to be abstracted easily. After the first bromine substitution, the second radical can be formed either in the 3 position (11a) or in the $\mathrm{H}_{3} \mathrm{C}(7 / 8)$ group (6a). Radical 11a is calculated to be more stable than $\mathbf{6 a}$, but the abstraction of the second methylene hydrogen to yield 11a is hindered, since the proximity of the bromine radical must overcome the increased Van der Waals repulsive forces, due to the bromine already present and the two phenyls at the 2- and 4-positions. This hydrogen can be abstracted only after the inversion of the BrHC(3) group, a process being hindered, as noted above. On the other hand, there are two symmetrically located methyls that can react freely with the proton abstracting radical. For the additional brominations, the stability difference between $7 \mathbf{a}$ and $7 \mathbf{b}$ radicals only in the case of PM3 calculation favors 7a and even in this case the energy difference is small. Concerning the relative stability of the radicals $\mathbf{8 a}$ and $\mathbf{8 b}$, only the PM3 method gives results favoring radical 8b. For radicals 9a and 9b both DFT and PM3 calculations give priority to radical 9a. The small energy differences between the successive bromination products justify the isolation of product mixtures differing by one bromine atom. The absence of brominated products on both phenyl rings and on the condensed aromatic can be attributed to the combined electron withdrawing effect of the $\mathrm{C}(\mathrm{Ph})=\mathrm{N}$ groups. To the contrary, in the case of $1 H-1,5$ benzodiazepines, the bromination under the same experimental conditions on the condensed aromatic ring is the predominant one. ${ }^{16}$ Finally, in the case of bromination with $\mathrm{KBrO}_{3} / \mathrm{NaHSO}_{3}$ in a dual polar solvent $\left(\mathrm{H}_{2} \mathrm{O} / \mathrm{AcOEt}\right)$ the reaction follows a polar mechanism of electrophilic substitution that first leads to monobromination on the $\mathrm{H}_{2} \mathrm{C}(3)$ allylic position followed by the second substitution on the same carbon, because of the strong deactivation of the other sites of the molecule.

In conclusion, a facile, quick and environmentally friendly synthesis of 4-phenyl-3H-1,5benzodiazepines under microwave irradiation using a catalytic amount of acetic acid has been achieved in excellent yield. In addition, from the theoretical study of the free radical bromination selectivity, it can be concluded that prediction of the bromination products is in accordance with the experimental results. The PM3 method predicts the stability of the intermediate radicals better than AM1 and in almost all cases is as good as DFT. A full assignment of ${ }^{1} \mathrm{H}$ - and ${ }^{13} \mathrm{C}$ NMR chemical shifts of all studied compounds has also been achieved and a very good 
approximation of chemical shifts was calculated by the B3LYP/6-31G(d)//B3LYP/6-311G(d) method. In addition, the inversion energy of the $\mathrm{H}_{2} \mathrm{C}(3)$ group was calculated by AM1 or PM3 using the reaction path method and was found to be $\sim 8.6$ or $\sim 9.0 \mathrm{kcal} / \mathrm{mol}$, respectively, very close to the experimental value of $c a .12 .4 \mathrm{kcal} / \mathrm{mol}$.

\section{Experimental Section}

General Procedures. Melting points were measured with a Kofler hot-stage apparatus and are uncorrected. Column chromatography was performed on 230-400 mesh silica gel (Merck) and preparative TLC plates with silica gel $60 \mathrm{~F}_{254}$ (Merck) were used. A mixture of petroleum ether/AcOEt, (20:1) was used as eluent for all chromatographic separations. Petroleum ether refers to the fraction boiling between 60 and $80{ }^{\circ} \mathrm{C}$. IR spectra were recorded as thin films or $\mathrm{KBr}$ pellets either on a Perkin-Elmer 297 or on a Perkin-Elmer 1650 FT-IR spectrometer and are reported in wave numbers $\left(\mathrm{cm}^{-1}\right)$. NMR spectra were recorded at room temperature on a Bruker AM 300 spectrometer at $300 \mathrm{MHz}$ for ${ }^{1} \mathrm{H}$ and $75 \mathrm{MHz}$ for ${ }^{13} \mathrm{C}$, respectively, using $\mathrm{CDCl}_{3}$ as solvent. Chemical shifts are expressed in $\delta$ values ( $\mathrm{ppm}$ ) relative to TMS as internal standard for ${ }^{1} \mathrm{H}$ and relative to TMS $(0.00 \mathrm{ppm})$ or to $\mathrm{CDCl}_{3}(77.05 \mathrm{ppm})$ for ${ }^{13} \mathrm{C}-\mathrm{NMR}$ spectra. Coupling constants ${ }^{n} J$ values are reported in Hz. Low resolution electron impact mass spectra (EIMS) were obtained on a VG TS-250 instrument and are reported in $\mathrm{m} / \mathrm{z}$ (rel. int. \%). Elemental analyses were performed on a Perkin-Elmer 2400-II CHN analyzer. Structural assignments of the derived compounds were established by analysis of their combined spectroscopic data.

Theoretical calculations. The minimum energy conformation of each compound was computed with the AM1 and PM3 methods as implemented in the MOPAC package ${ }^{17}$ and referred to vacuum. All geometry optimizations were carried out without symmetry constraints and stationary points were refined by minimization of the gradient norm of the energy to at least 0.01 $\mathrm{kcal} / \mathrm{mol}$, using the LET and PRECISE keywords. The heats of formation $\left(\Delta H_{f}\right)$ for radicals were calculated by the unrestricted (UHF) wave function using the keyword LET. The DFT geometry optimizations and total energy calculations of the radicals have been performed with the standard 6-31G(d) basis set by using the unrestricted B3LYP functional ${ }^{18}$ as implemented in the Gaussian 2003 package. ${ }^{19}$ Moreover, the complete assignment of ${ }^{1} \mathrm{H}$ - and ${ }^{13} \mathrm{C}-\mathrm{NMR}$ signals was possible using 1D and 2D experiments in conjunction with DFT/GIAO calculated isotropic magnetic shielding ${ }^{13,14}$ at the B3LYP density functional level. The geometries of selected compounds have been optimized using the 6-31G(d) basis set, whereas the isotropic nuclear magnetic shielding constants (IMS) were calculated by using 6-311G(d) basis set and the results are presented as the

differences $\triangle \mathrm{IMS}$ relatively to TMS shielding calculated at the same level of theory. The calculated values are very close to the experimental data. 


\section{Synthesis of 4-phenyl-3H-1,5-benzodiazepines (3) under microwave irradiation. General procedure}

The 1,3-dicarbonyl compound 2 (1.0 mmol), 1,2-phenylenediamine derivative 1 (1.5 mmol) and a trace of acetic acid were mixed thoroughly and were irradiated in a Milestone Ethos 1600 microwave oven at a power and time indicated in Table 1. The diazepine $\mathbf{3}$ was isolated from the reaction mixture by column chromatography.

2-Methyl-4-phenyl-3H-1,5-benzodiazepine (3a). 93\% Yield, mp 87-88 ${ }^{\circ} \mathrm{C}$ (lit. ${ }^{20} \mathrm{mp} 88{ }^{\circ} \mathrm{C}$ ). ${ }^{1} \mathrm{H}$ NMR $\delta$ ppm: $2.30\left(3 \mathrm{H}, \mathrm{s}, \mathrm{CH}_{3}-2\right), 3.3(2 \mathrm{H}$, br s, 3), 7.23-7.31 (2H, m, 7,8), 7.40-7.50 (3H, m, $\left.3^{\prime}, 4^{\prime}, 5^{\prime}\right), 7.42-7.48(1 \mathrm{H}, \mathrm{m}, 9), 7.51-7.57(1 \mathrm{H}, \mathrm{m}, 6), 8.01-8.07\left(2 \mathrm{H}, \mathrm{m}, 2^{\prime}, 6^{\prime}\right) .{ }^{13} \mathrm{C} \mathrm{NMR} \delta \mathrm{ppm}$ : $27.0\left(\mathrm{CH}_{3}-2\right), 38.5$ (3), 125.0 (8), 125.2 (7), 127.6 (6), 128.1 (2',6'), 128.4 (9), 128.7 (3',5'), 130.7 (4'), $137.0\left(1^{\prime}\right), 140.2$ (5a), 140.6 (9a), 153.3 (4), 157.9 (2). EIMS: $m / z(\%) 234\left(\mathrm{M}^{+} \cdot, 63\right)$, $219(30), 132$ (51), 103 (62).

2,4-Diphenyl-3H-1,5-benzodiazepine (3b). 95\% Yield, mp 138-140 ${ }^{\circ} \mathrm{C}$ (ethanol) (lit. ${ }^{9 \mathrm{a}} \mathrm{mp}$ 137.5-139 $\left.{ }^{\circ} \mathrm{C}\right) .{ }^{1} \mathrm{H}$ NMR $\delta$ ppm: $3.2(2 \mathrm{H}$, br s, 3), $7.34(2 \mathrm{H}, \mathrm{ddd}, J=7.7,6.0,2.0 \mathrm{~Hz}, 7,8), 7.36-$

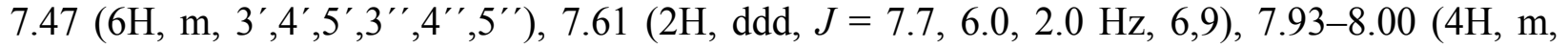
$\left.2^{\prime}, 6^{\prime}, 2^{\prime \prime}, 6^{\prime \prime}\right) .{ }^{13} \mathrm{C}$ NMR $\delta$ ppm: $34.8(3), 125.4$ (7,8), $128.1\left(2^{\prime}, 6^{\prime}, 2^{\prime \prime}, 6^{\prime \prime}\right), 128.6\left(3^{\prime}, 5^{\prime}, 3^{\prime \prime}, 5^{\prime \prime}\right)$, $128.7(6,9), 130.5\left(4^{\prime}, 4^{\prime \prime}\right), 137.2\left(1^{\prime}, 1^{\prime \prime}\right), 140.7$ (5a,9a), $154.1(2,4)$. EIMS: m/z (\%) $296\left(\mathrm{M}^{+}\right.$. 100), 219 (21), 194 (37), 165 (15), 103 (67).

2,7,8-Trimethyl-4-phenyl-3H-1,5-benzodiazepine (3c). 96\% Yield, mp 116-118 ${ }^{\circ} \mathrm{C}$ (lit. ${ }^{10} \mathrm{mp}$ 115-117 $\left.{ }^{\circ} \mathrm{C}\right) .{ }^{1} \mathrm{H}$ NMR $\delta$ ppm: $2.26\left(3 \mathrm{H}, \mathrm{s}, \mathrm{CH}_{3}-2\right), 2.31\left(6 \mathrm{H}, \mathrm{s}, \mathrm{CH}_{3}-7, \mathrm{CH}_{3}-8\right), 3.2$ (2H, br s, 3), $7.22(1 \mathrm{H}, \mathrm{s}, 9), 7.31(1 \mathrm{H}, \mathrm{s}, 6), 7.41-7.45\left(3 \mathrm{H}, \mathrm{m}, 3^{\prime}, 4^{\prime}, 5^{\prime}\right), 7.99-8.03\left(2 \mathrm{H}, \mathrm{m}, 2^{\prime}, 6^{\prime}\right) .{ }^{13} \mathrm{C} \mathrm{NMR} \delta$ ppm: $19.25\left(\mathrm{CH}_{3}-7\right), 19.33\left(\mathrm{CH}_{3}-8\right), 26.8\left(\mathrm{CH}_{3}-2\right), 38.3$ (3), 127.9 (2',6'), 128.0 (9), 128.6 $\left(3^{\prime}, 5^{\prime}\right), 128.7$ (6), 130.3 (4'), 133.8 (7), 134.1 (8), 137.1 (1'), 138.2 (9a), 138.5 (5a), 151.9 (4), 156.4 (2). EIMS: $m / z(\%) 262\left(\mathrm{M}^{+} \cdot, 100\right), 248$ (30), 220 (15), 160 (14).

7,8-Dimethyl-2,4-diphenyl-3H-1,5-benzodiazepine (3d). White needles (97\%), mp 167-168 ${ }^{\circ} \mathrm{C}$ (ethanol) (lit. $\left.{ }^{10} \mathrm{mp} 163-164{ }^{\circ} \mathrm{C}\right) .{ }^{1} \mathrm{H}$ NMR $\delta$ ppm: $2.36\left(6 \mathrm{H}, \mathrm{s}, \mathrm{CH}_{3}-7, \mathrm{CH}_{3}-8\right), 3.3(2 \mathrm{H}$, br s, 3),

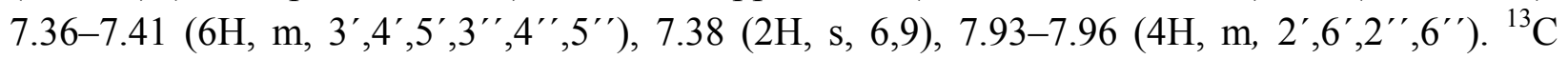
NMR $\delta$ ppm: $19.5\left(\mathrm{CH}_{3}-7, \mathrm{CH}_{3}-8\right), 34.9$ (3), $128.1\left(2^{\prime}, 6^{\prime}, 2^{\prime \prime}, 6^{\prime \prime}\right), 128.7\left(3^{\prime}, 5^{\prime}, 3^{\prime \prime}, 5^{\prime \prime}\right), 129.1$ $(6,9), 130.4\left(4^{\prime}, 4^{\prime \prime}\right), 134.6(7,8), 137.5\left(1^{\prime}, 1^{\prime \prime}\right), 138.8$ (5a,9a), $153.0(2,4)$. EIMS: $m / z(\%) 324$ $\left(\mathrm{M}^{+} \cdot, 100\right), 247$ (15), 222 (35), 207 (20), 103 (47).

3,7,8-Trimethyl-2,4-diphenyl-3H-1,5-benzodiazepine (3e). $62 \%$ Yield, oil. ${ }^{1} \mathrm{H}$ NMR $\delta$ ppm: $0.85\left(3 \mathrm{H}, \mathrm{d}, J=7.15 \mathrm{~Hz}, \mathrm{CH}_{3}-3\right), 2.36\left(6 \mathrm{H}, \mathrm{s}, \mathrm{CH}_{3}-7, \mathrm{CH}_{3}-8\right), 5.56$ (q, $\left.J=7.15 \mathrm{~Hz}, 3\right), 7.36-7.40$ $\left(6 \mathrm{H}, \mathrm{m}, 3^{\prime}, 4^{\prime}, 5^{\prime}, 3^{\prime \prime}, 4^{\prime \prime}, 5^{\prime \prime}\right), 7.39(2 \mathrm{H}, \mathrm{s}, 6,9), 7.85-7.90\left(4 \mathrm{H}, \mathrm{m}, 2^{\prime}, 6^{\prime}, 2^{\prime \prime}, 6^{\prime \prime}\right) .{ }^{13} \mathrm{C} \mathrm{NMR} \delta \mathrm{ppm}:$ $9.4\left(\mathrm{CH}_{3}-3\right), 19.4\left(\mathrm{CH}_{3}-7, \mathrm{CH}_{3}-8\right), 41.8$ (3), $127.9\left(2^{\prime}, 6^{\prime}, 2^{\prime \prime}, 6^{\prime \prime}\right), 128.6\left(3^{\prime}, 5^{\prime}, 3^{\prime \prime}, 5^{\prime \prime}\right), 129.1$ $(6,9), 130.1\left(4^{\prime}, 4^{\prime \prime}\right), 134.6(7,8), 137.5\left(1^{\prime}, 1^{\prime \prime}\right), 139.3$ (5a,9a), $156.5(2,4)$. Anal. Calcd. for $\mathrm{C}_{24} \mathrm{H}_{22} \mathrm{~N}_{2}$ (338.45): C 85.17; H 6.55; N 8.28. Found: C 85.38; H 6.74; N 8.19.

5,6-Dimethyl-2-phenyl-1H-benzimidazole (4). Isolated in $20 \%$ yield. $\mathrm{Mp} 250-252{ }^{\circ} \mathrm{C}$ (lit. ${ }^{21} \mathrm{mp}$ 251-253 $\left.{ }^{\circ} \mathrm{C}\right) .{ }^{1} \mathrm{H}$ NMR $\delta$ ppm: $2.34\left(6 \mathrm{H}, \mathrm{s}, \mathrm{CH}_{3}-5, \mathrm{CH}_{3}-6\right), 5.1(1 \mathrm{H}$, br s, NH), 7.35-7.42 (1H, m, $\left.4^{\prime}\right), 7.38(2 \mathrm{H}, \mathrm{s}, 4,7), 7.38-7.46\left(2 \mathrm{H}, \mathrm{m}, 3^{\prime}, 5^{\prime}\right), 8.13-8.17$ (2H, m, 2',6'). ${ }^{13} \mathrm{C}$ NMR $\delta$ ppm: 20.4 
$\left(\mathrm{CH}_{3}-5, \mathrm{CH}_{3}-6\right), 115.3$ (br, 4,7), $126.7\left(2^{\prime}, 6^{\prime}\right), 128.8$ (3',5'), $129.6\left(4^{\prime}\right), 130.3\left(1^{\prime}\right), 131.5(5,6)$, 137.9 (br 3a,7a), $151.2(2)$.

\section{NBS brominations of compound 3d. General procedure}

A magnetically stirred mixture of compound 3d $(0.324 \mathrm{~g}, 1 \mathrm{mmol})$ and NBS (0.199 g, $1.1 \mathrm{mmol})$ in anhydrous $\mathrm{CCl}_{4}(10 \mathrm{~mL})$ was refluxed for $30 \mathrm{~min}$, while irradiating by a $200 \mathrm{~W}$ projector light bulb. After cooling at $6^{\circ} \mathrm{C}$, the succinimide crystals formed were removed by filtration. The filtrate was evaporated and after column chromatography afforded compounds $5(0.081 \mathrm{~g}, 20 \%)$ and $6(0.218 \mathrm{~g}, 45 \%)$.

3-Bromo-7,8-dimethyl-2,4-diphenyl-3H-1,5-benzodiazepine (5). Yellow solid, mp 140$142{ }^{\circ} \mathrm{C} .{ }^{1} \mathrm{H}$ NMR $\delta$ ppm: 2.42 (6H, s, $\left.\mathrm{CH}_{3}-7, \mathrm{CH}_{3}-8\right), 6.99$ (1H, s, 3), 7.40-7.51 (6H, m, 3', 4', 5', $\left.\mathrm{H}-3^{\prime \prime}, 4^{\prime \prime}, 5^{\prime \prime}\right), 7.49(2 \mathrm{H}, \mathrm{s}, 6,9), 7.85-7.90\left(4 \mathrm{H}, \mathrm{m}, 2^{\prime}, 6^{\prime}, 2^{\prime \prime}, 6^{\prime \prime}\right) .{ }^{13} \mathrm{C} \mathrm{NMR} \delta$ ppm: $19.7\left(\mathrm{CH}_{3}-7\right.$, $\left.\mathrm{CH}_{3}-8\right), 35.5$ (3), 127.8 (2',6',2', $\left.6^{\prime \prime}\right), 129.0\left(3^{\prime}, 5^{\prime}, 3^{\prime \prime}, 5^{\prime \prime}\right), 129.5(6,9), 130.8\left(4^{\prime}, 4^{\prime \prime}\right), 136.6$ (7,8), $137.4\left(1^{\prime}, 1^{\prime \prime}\right), 139.1$ (5a,9a), $149.4(2,4)$. EIMS: $m / z(\%)$ 402/404 $\left(\mathrm{M}^{+} \cdot, 7\right), 323$ [(M-Br) ${ }^{+}$, 100], 220 (23). Anal. Calcd. for $\mathrm{C}_{23} \mathrm{H}_{19} \mathrm{BrN}_{2}$ (403.31): C 68.49; H 4.75; N 6.95. Found: C 68.68; H 4.64; N 6.73.

3-Bromo-7-(bromomethyl)-8-methyl-2,4-diphenyl-3H-1,5-benzodiazepine (6). Mp 188$190{ }^{\circ} \mathrm{C} .{ }^{1} \mathrm{H}$ NMR $\delta$ ppm: $2.57\left(3 \mathrm{H}, \mathrm{s}, \mathrm{CH}_{3}-8\right), 4.64\left(2 \mathrm{H}, \mathrm{s}, \mathrm{BrCH}_{2}-7\right), 6.99(1 \mathrm{H}, \mathrm{s}, 3), 7.45-7.51$ $\left(6 \mathrm{H}, \mathrm{m}, 3^{\prime}, 4^{\prime}, 5^{\prime}, 3^{\prime \prime}, 4^{\prime \prime}, 5^{\prime \prime}\right), 7.52(1 \mathrm{H}, \mathrm{s}, 9), 7.67(1 \mathrm{H}, \mathrm{s}, 6), 7.87-7.92\left(4 \mathrm{H}, \mathrm{m}, 2^{\prime}, 6^{\prime}, 2^{\prime \prime}, 6^{\prime \prime}\right) .{ }^{13} \mathrm{C}$ NMR $\delta$ ppm: $18.7\left(\mathrm{CH}_{3}-8\right), 31.7\left(\mathrm{BrCH}_{2}-7\right), 34.9$ (3), $127.8\left(2^{\prime}, 6^{\prime}\right), 127.9\left(2^{\prime \prime}, 6^{\prime \prime}\right), 129.00$ $\left(3^{\prime}, 5^{\prime}, 3^{\prime \prime}, 5^{\prime \prime}\right), 130.5(6), 130.7(9), 131.0\left(4^{\prime}\right), 131.2\left(4^{\prime \prime}\right), 135.1(7), 136.4(8), 137.1\left(1^{\prime \prime}\right), 137.2$

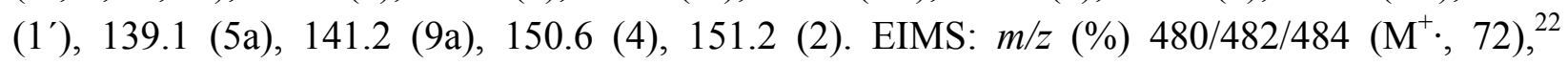
401/403 [(M-Br) $\left.{ }^{+}, 61\right], 322$ [(M-2Br) , 41], 103 (100); Anal. Calcd. for $\mathrm{C}_{23} \mathrm{H}_{18} \mathrm{Br}_{2} \mathrm{~N}_{2}(482.21)$ : C 57.29; H 3.76; N 5.81. Found: C 57.15; H 3.80; N 5.73.

When the bromination was repeated with 2.2 equivalents of NBS an inseparable mixture of the dibromo derivative 6 (52\% yield) and the tribromo derivative 7 (24\% yield) was obtained after purification of the crude reaction mixture on a preparative TLC plate. The yield ratio was calculated from the ${ }^{1} \mathrm{H}-\mathrm{NMR}$ of the mixture.

3-Bromo-7,8-bis(bromomethyl)-2,4-diphenyl-3H-1,5-benzodiazepine (7). ${ }^{1} \mathrm{H}$ NMR $\delta$ ppm: $4.78\left(4 \mathrm{H}, \mathrm{s}, \mathrm{BrCH}_{2}-7\right.$ and $\left.\mathrm{BrCH}_{2}-8\right), 7.00$ (1H, s, 3), 7.42-7.52 (6H, m, 3',4',5',3' , , 4' , 5' '), 7.70 $(2 \mathrm{H}, \mathrm{s}, 6,9), 7.88-7.95\left(4 \mathrm{H}, \mathrm{m}, 2^{\prime}, 6^{\prime}, 2^{\prime \prime}, 6^{\prime \prime}\right) .{ }^{13} \mathrm{C} \mathrm{NMR} \delta \mathrm{ppm}: 29.7\left(\mathrm{BrCH}_{2}-7, \mathrm{BrCH}_{2}-8\right), 34.5$ (3), $127.9\left(2^{\prime}, 6^{\prime}, 2^{\prime \prime}, 6^{\prime \prime}\right), 129.0\left(3^{\prime}, 5^{\prime}, 3^{\prime \prime}, 5^{\prime \prime}\right), 131.5(6,9), 131.6\left(4^{\prime}, 4^{\prime \prime}\right), 135.0(7,8), 136.7$ $\left(1^{\prime}, 1^{\prime \prime}\right), 141.1$ (5a,9a), $151.9(2,4)$. EIMS: $m / z(\%)$ 558/560/562/564 $\left(\mathrm{M}^{+} \cdot, 9\right){ }^{22}$

When the bromination was repeated with 3.3 equivalents of NBS an inseparable mixture of the tribromo-derivative 7 (46\% yield) and the tetrabromo-derivative 8 (26\% yield) was obtained after purification of the crude reaction mixture on a preparative TLC plate. The yield ratio was calculated from the ${ }^{1} \mathrm{H}-\mathrm{NMR}$ of the mixture.

3-Bromo-8-(bromomethyl)-7-(dibromomethyl)-2,4-diphenyl-3H-1,5-benzodiazepine (8). ${ }^{1} \mathrm{H}$ NMR $\delta$ ppm: $4.72\left(2 \mathrm{H}, \mathrm{s}, \mathrm{BrCH}_{2}-8\right), 7.00(1 \mathrm{H}, \mathrm{s}, 3), 7.19\left(1 \mathrm{H}, \mathrm{s}, \mathrm{Br}_{2} \mathrm{CH}-7\right), 7.42-7.52(6 \mathrm{H}, \mathrm{m}$, $\left(3^{\prime}, 4^{\prime}, 5^{\prime}, 3^{\prime \prime}, 4^{\prime \prime}, 5^{\prime \prime}\right), 7.62(1 \mathrm{H}, \mathrm{s}, 9), 7.88-7.95\left(4 \mathrm{H}, \mathrm{m}, 2^{\prime}, 6^{\prime}, 2^{\prime \prime}, 6^{\prime \prime}\right), 8.26(1 \mathrm{H}, \mathrm{s}, 6) .{ }^{13} \mathrm{C} \mathrm{NMR} \delta$ 
ppm: $28.9\left(\mathrm{BrCH}_{2}-(8), 34.4(3), 36.2\left(\mathrm{Br}_{2} \mathrm{CH}-7\right), 128.0\right.$ and $128.1\left(2^{\prime}, 6^{\prime}\right.$ and $\left.2^{\prime \prime}, 6^{\prime \prime}\right), 129.05$ and 129.09 (3',5' and $\left.3^{\prime \prime}, 5^{\prime \prime}\right), 130.7(9), 131.1(8), 131.3(6), 131.4$ and 131.5 (4' and $\left.4^{\prime \prime}\right), 136.5$ and $136.6\left(1^{\prime}\right.$ and $\left.1^{\prime \prime}\right), 138.5$ (7), 141.5 (5a), 141.6 (9a), 152.5 (4), 152.9 (2). EIMS: $m / z$ (\%) $642 / 644 / 646 / 648 / 650\left(\mathrm{M}^{+} \cdot, 22\right){ }^{22} 322$ (29), 103 (49).

When the bromination was repeated with 4.4 equivalents of NBS with reaction time $2 \mathrm{~h}$, an inseparable mixture of the tetrabromo derivative 8 (50\% yield) and the pentabromo derivative 9 ( $23 \%$ yield) was obtained after purification of the crude reaction mixture on a preparative TLC plate. The yields were calculated from the ${ }^{1} \mathrm{H}-\mathrm{NMR}$ of the mixture. However, bromination with 6.0 equivalents of NBS and reaction time $2.5 \mathrm{~h}$ resulted to the formation of 9 as the only product, obtained in $95 \%$ yield after purification of the crude reaction mixture on a preparative TLC plate. 3-Bromo-7,8-bis(dibromomethyl)-2,4-diphenyl-3H-1,5-benzodiazepine (9). Mp 188-189 ${ }^{\circ} \mathrm{C}$. ${ }^{1} \mathrm{H}$ NMR $\delta$ ppm: 7.00 (1H, s, 3), 7.23 (2H, br s, Br $\left.{ }_{2} \mathrm{CH}-7, \mathrm{Br}_{2} \mathrm{CH}-8\right), 7.44-7.52$ (m, 3',5',3' , H$\left.5^{\prime \prime}\right), 7.47-7.55\left(2 \mathrm{H}, \mathrm{m}, 4^{\prime}, 4^{\prime \prime}\right), 7.90-7.95\left(4 \mathrm{H}, \mathrm{m}, 2^{\prime}, 6^{\prime}, 2^{\prime \prime}, 6^{\prime \prime}\right), 8.00(2 \mathrm{H}, \mathrm{br} \mathrm{s}, 6,9) .{ }^{13} \mathrm{C} \mathrm{NMR} \delta$

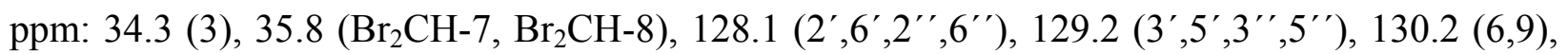
$131.7\left(4^{\prime}, 4^{\prime \prime}\right), 135.9$ (7,8), 136.5 (1',1' $), 141.6$ (5a,9a), 153.4 (2,4). EIMS: m/z (\%) 714/716/718/720/722/724 ( $\mathrm{M}^{+}$, 10), 321 (100). Anal. Calcd. for $\mathrm{C}_{23} \mathrm{H}_{15} \mathrm{Br}_{5} \mathrm{~N}_{2}$ (718.90): C 38.43; H 2.10; N 3.90. Found: C 38.25; H 2.25; N 3.73.

When the bromination was repeated with 7 equivalents of NBS for $4 \mathrm{~h}$ the pentabromoderivative 9 (65\% yield) and the hexabromo-derivative 10 (14\% yield) were obtained after separation of the crude reaction mixture on a preparative TLC plate.

3-Bromo-8-(dibromomethyl)-2,4-diphenyl-7-(tribromomethyl)-3H-1,5-benzodiazepine (10). Mp 93-95 ${ }^{\circ} \mathrm{C} .{ }^{1} \mathrm{H}$ NMR $\delta$ ppm: 7.04 (1H, s, 3), 7.45-7.57 (6H, m, 3',4',5',3' , $\left.4^{\prime \prime}, 5^{\prime \prime}\right), 7.84$ (1H, $\left.\mathrm{s}, \mathrm{Br}_{2} \mathrm{CH}-8\right), 7.89-7.99$ (4H, m, 2',6', $\left.2^{\prime \prime}, 6^{\prime \prime}\right), 8.25(1 \mathrm{H}, \mathrm{s}, 6), 8.50(1 \mathrm{H}, \mathrm{s}, 9) .{ }^{13} \mathrm{C} \mathrm{NMR} \delta \mathrm{ppm}$ : $30.0\left(\mathrm{Br}_{3} \mathrm{C}-7\right), 34.3$ (3), $37.2\left(\mathrm{Br}_{2} \mathrm{CH}-8\right), 128.17$ and 128.22 (2',6' and $\left.2^{\prime \prime}, 6^{\prime \prime}\right), 129.2\left(3^{\prime}, 5^{\prime}\right.$ and $\left.3^{\prime \prime}, 5^{\prime \prime}\right), 127.7$ (6), 131.79 and 131.84 (4' and 4'), 136.0 (9), 136.43 and 136.46 ( $1^{\prime}$ and $\left.1^{\prime \prime}\right)$, 137.0 (7), 138.5 (8), 139.7 (5a), 142.6 (9a), 153.5 (4), 153.7 (2). EIMS: $m / z$ (\%) 792/794/796/798/800/802/804 (M+, 8), 320 (26). Anal. Calcd. for $\mathrm{C}_{23} \mathrm{H}_{14} \mathrm{Br}_{6} \mathrm{~N}_{2}$ (797.80): C 34.63; H 1.77; N 3.51. Found: C 34.50; H 1.80; N 3.70.

\section{Bromination of compound 3d with $\mathrm{KBrO}_{3} / \mathrm{NaHSO}_{3}$}

To a solution of $\mathrm{KBrO}_{3}(0.50 \mathrm{~g}, 3 \mathrm{mmol})$ in water $(1.5 \mathrm{~mL})$ was added the benzodiazepine $3 \mathrm{~d}$ $(0.324 \mathrm{~g}, 1 \mathrm{mmol})$ in ethyl acetate $(2 \mathrm{~mL})$, followed by a solution of $\mathrm{NaHSO}_{3}(0.31 \mathrm{~g}, 3 \mathrm{mmol})$ in water $(3 \mathrm{~mL})$ over a period of about $15 \mathrm{~min}$, and the mixture was stirred at room temperature for $4 \mathrm{~h}$. The mixture was poured into $20 \mathrm{~mL}$ of dichloromethane. After separation of the phases, the aqueous layer was extracted twice with dichloromethane, and the combined organic layer was washed with aqueous $\mathrm{Na}_{2} \mathrm{~S}_{2} \mathrm{O}_{4}$ solution and dried over anhydrous $\mathrm{MgSO}_{4}$. The solvent was evaporated and the residue was purified by column chromatography to afford in order of elution: 3,3-Dibromo-7,8-dimethyl-2,4-diphenyl-3H-1,5-benzodiazepine (11). Yellow solid, mp 226$228{ }^{\circ} \mathrm{C}$; yield $0.27 \mathrm{~g}(56 \%) .{ }^{1} \mathrm{H}$ NMR $\delta$ ppm: $2.43\left(6 \mathrm{H}, \mathrm{s}, \mathrm{CH}_{3}-7\right.$ and $\left.\mathrm{CH}_{3}-8\right), 7.42-7.50(6 \mathrm{H}, \mathrm{m}$, $\left.3^{\prime}, 4^{\prime}, 5^{\prime}, 3^{\prime \prime}, 4^{\prime \prime}, 5^{\prime \prime}\right), 7.67$ ( $\left.2 \mathrm{H}, \mathrm{s}, 6,9\right), 8.10-8.16$ (4H, m, 2',6', $\left.2^{\prime \prime}, 6^{\prime \prime}\right) .{ }^{13} \mathrm{C}$ NMR $\delta$ ppm: 19.5 
$\left(\mathrm{CH}_{3}-7\right.$ and $\left.\mathrm{CH}_{3}-8\right), 29.7$ (3), $128.2\left(2^{\prime}, 6^{\prime}, 2^{\prime \prime}, 6^{\prime \prime}\right), 129.0\left(3^{\prime}, 5^{\prime}, 3^{\prime \prime}, 5^{\prime \prime}\right), 131.2\left(4^{\prime}, 4^{\prime \prime}\right), 131.5$ $(6,9), 133.2(7,8), 137.4\left(1^{\prime}, 1^{\prime \prime}\right), 138.5$ (5a,9a), $157.3(2,4)$. EIMS: $m / z(\%)$ 480/482/484 $\left(\mathrm{M}^{+}\right.$., 28), ${ }^{22} 401 / 403$ [(M-Br) $\left.{ }^{+}, 36\right], 322$ (9), 77 (100). Anal. Calcd. for $\mathrm{C}_{23} \mathrm{H}_{18} \mathrm{Br}_{2} \mathrm{~N}_{2}$ (482.21): C 57.29; H 3.76; N 5.81. Found: C 57.48; H 3.64; N 5.92.

Compound 5 in $23 \%$ yield.

\section{Supplementary Information available}

\section{References and Notes}

1. (a) Schutz, H. In Benzodiazepines; Springer: Heildeberg, 1982. (b) Landquist, J. K. In Comprehensive Heterocyclic Chemistry; Katritzky, A. R.; Rees, C. W. Eds.; Pergamon: Oxford, 1984. Vol. 1, pp 166-170.

2. (a) Randall, L. O.; Kappel, B. In Benzodiazepines; Garattini, S.; Mussini, E.; Randall, L. O. Eds.; Raven Press: New York, 1973. p. 27 and references cited therein; (b) Di Braccio, M.; Grossi, G.; Roma, G.; Vargiu, L.; Mura, M.; Marongiu, M. E. Eur. J. Med. Chem. 2001, 36, 935.

3. (a) Haris, R. C.; Straley, J. M. U.S. Patent 1,537,757, 1968; Chem. Abstr. 1970, 73, 100054w.

4. (a) De Baun, J. R.; Pallos, F. M.; Baker, D. R. U.S. Patent 3,978,227, 1976; Chem. Abstr. 1977, 86, 5498d.

5. (a) Essaber, M.; Baouid, A.; Hasnaoui, A.; Benharref, A.; Lavergne, J. P. Synth. Commun. 1998, 28, 4097. (b) El-Sayed, A. M.; Abdel-Ghany, H.; El-Saghier, A. M. M. Synth. Commun. 1999, 29, 3561. (c) Reddy, K. V. V.; Rao, P. S.; Ashok, D. Synth. Commun. 2000, 30, 1825. (d) Nabih, K.; Baouid, A.; Hasnaoui, A.; Kenz, A. Synth. Commun. 2004, 34, 1532.

6. (a) Balakrishna, M. S.; Kaboudin, B. Tetrahedron Lett. 2001, 42, 1127. (b) Curini, M.; Epifano, F.; Marcotullio, M. C.; Rosati, O. Tetrahedron Lett. 2001, 42, 3193. (c) Zhong, W.; Zhang, Y.; Chen, X. Tetrahedron Lett. 2001, 42, 73.

7. (a) Thakuria, H.; Pramanik, A.; Borah, B. M.; Das, G. Tetrahedron Lett. 2006, 47, 3135. (b) Kumar, R.; Chaudhary, P.; Nimesh, S.; Verma, A. K.; Chandra, R. Green Chemistry 2006, 8, 519. (c) Du, Y.; Tian, F.; Zhao, W. Synth. Commun. 2006, 36, 1661.

8. (a) Ried, W.; Stahlhofen, P. Chem. Ber. 1957, 90, 815. (b) Reid, W.; Torinus, E. Chem. Ber. 1959, 92, 2902.

9. (a) Despinoy, C.; Lloyd, D.; McNab, H.; Reed, D. Tetrahedron 1998, 54, 9667. (b) Mansour, O.; Szymonski, B.; Thomasson, F.; Morand, J. M.; Cussac, M. J. Heterocyclic Chem. 2001, 38, 641. (c) Guzen, K.P.; Cella, R.; Stefani, H. A. Tetrahedron Lett. 2006, 47, 8133. (d) Polshettiwar, V.; Varka, R.S. Tetrahedron Lett., 2008, 49, 397.

10. Ried, W.; Teubner, R. Liebigs Ann. Chem. 1978, 741. 
11. Kikuchi, D.; Sakaguchi, S.; Ishii, Y. J. Org. Chem. 1998, 63, 6023.

12. Ahmad, R.; Zia-ul-Haq, M.; Duddeck, H.; Stefaniak, L.; Sitkowski, J. Monatsh. Chem. 1997, 128,633 .

13. (a) Ditchfield, R. Mol. Phys. 1974, 27, 789. (b) Barfiled, M.; Fagerness, P. J. J. Am. Chem. Soc. 1997, 119, 8699. (c) Manaj, J. M.; Maciewska, D.; Waver, I. Magn. Reson. Chem. 2000, $38,482$.

14. (a) Yüksek, H.; Cakmak, I.; Sadi, S.; Alkan, M.; Baykara, H. Int. J. Mol. Sci. 2005, 219. (b) Wolinski, K.; Hilton, K. J. F.; Pulay, P. J. Am. Chem. Soc. 1990, 112, 8251.

15. (a) Greenwood, J. R.; Vaccarella, G.; Capper, H. R.; Mewett, K. N.; Allan, R. D.; Johnston, G. A. R. J. Mol. Struct. (Theochem) 1996, 368, 235. (b) March, J. Advanced Organic Chemistry. Reactions, Mechanisms, and Structure, $3^{\text {rd }}$ Edn.; Wiley: New York, 1985; p. 625.

(c) Pearson, R. A.; Martin, J. C. J. Am. Chem. Soc. 1963, 85, 3142.

16. M. Pozarentzi, M.; Tsoleridis, C. A. Stephanidou-Stephanatou, J. Unpublished results.

17. Mopac2000 Ver 1.11. Fujitsu in Chem3D Ultra 7.0.

18. (a) Becke, A. D. J. Chem. Phys. 1993, 5648. (b) Lee, C.; Yang, W.; Parr, R. G. Phys. Rev. B 1988, 37, 785.

19. Frisch, M. J. T.; Trucks, G. W.; Schlegel, H. B.; Scuseria, G. E.; Robb, M. A.; Cheeseman, J. R.; Montgomery, J. A., Jr.; Vreven, T.; Kudin, K. N.; Burant, J. C.; Millam, J. M.; Iyengar, S. S.; Tomasi, J.; Barone, V.; Mennucci, B.; Cossi, M.; Scalmani, G.; Rega, N.; Petersson, G. A.; Nakatsuji, H.; Hada, M.; Ehara, M.; Toyota, K.; Fukuda, R.; Hasegawa, J.; Ishida, M.; Nakajima, T.; Honda, Y.; Kitao, O.; Nakai, H.; Klene, M.; Li, X.; Knox, J. E.; Hratchian, H. P.; Cross, J. B.; Adamo, C.; Jaramillo, J.; Gomperts, R.; Stratmann, R. E.; Yazyev, O.; Austin, A. J.; Cammi, R.; Pomelli, C.; Ochterski, J. W.; Ayala, P. Y.; Morokuma, K.; Voth, G. A.; Salvador, P.; Dannenberg, J. J.; Zakrzewski, V. G.; Dapprich, S.; Daniels, A. D.; Strain, M. C.; Farkas, O.; Malick, D. K.; Rabuck, A. D.; Raghavachari, K.; Foresman, J. B.; Ortiz, J. V.; Cui, Q.; Baboul, A. G.; Clifford, S.; Cioslowski, J.; Stefanov, B. B.; Liu, G.; Liashenko, A.; Piskorz, P.; Komaromi, I.; Martin, R. L.; Fox, D. J.; Keith, T.; Al-Laham, M. A.; Peng, C. Y.; Nanayakkara, A.; Challacombe, M.; Gill, P. M. W.; Johnson, B.; Chen, W.; Wong, M. W.; Gonzalez, C.; Pople, J. A. Gaussian03, revision B.02; Gaussian, Inc.: Pittsburgh PA. 2003.

20. Mannschreck, A.; Rissmann, G.; Vögtle, F.; Wild, D. Chem. Ber. 1967, 100, 335.

21. Zaika, L. L.; Joullié, M. M. J. Heterocyclic Chem. 1966, 3, 444.

22. The peak intensity refers to the higher peak of bromine containing ions. 